\title{
COMPARATIVE SEX CHROMOSOME HYBRIDIZATIONS IN RUMINANTIA*
}

\author{
Anna Kozubska-Sobocińska ${ }^{1}$, Barbara Rejduch ${ }^{1}$, \\ Barbara Danielak-Czech ${ }^{1}$, Marek Babicz ${ }^{2}$, Agnieszka Bąk ${ }^{1}$ \\ ${ }^{1}$ Department of Animal Cytogenetics and Molecular Genetics, National Research Institute of Animal \\ Production, 32-083 Balice n. Kraków, Poland \\ ${ }^{2}$ Department of Pig Breeding and Production Technology, University of Life Sciences, Akademicka \\ 13, 20-950 Lublin, Poland
}

\begin{abstract}
The syntenic conservation nature of some chromosomes enables the use of several molecular probes obtained from one species of animals to detect homologous DNA segments in other species. The aim of this study was to analyse homology between sex chromosomes in several species belonging to the suborder Ruminantia (sheep - Ovis aries, fallow deer - Dama dama, aoudad - Ammotragus lervia, red deer - Cervus elaphus) using bovine heterosome painting probes in FISH technique. The results obtained showed strong red fluorescence signals in small metacentric heterosomes $\mathbf{Y}$ and distinct yellow-green signals in large acrocentric chromosomes $X$ of all compared species.
\end{abstract}

Key words: Ruminantia, genetic conservatism, sex chromosomes, bovine heterosome probes, FISH

Genetic conservatism makes it possible to compare genomes of different species at the level of nucleotide sequences (Kozubska-Sobocińska et al., 2007, 2009 a; Rejduch et al., 2009), chromosome banding patterns (Di Berardino et al., 2001; Kozubska-Sobocińska et al., 2006, 2007) and groups of linked or syntenic genes that are often in the same relationships even in taxonomically distant species (Hayes, 1995; Danielak-Czech et al., 2010; Rejduch et al., 2010 a, 2010 b).

This syntenic conservation nature of some chromosomes makes it possible to use a number of molecular probes obtained by microdissection or chromosome sorting in one species of animals, for FISH chromosome painting in other species (Chowdhary et al., 1996; Révay et al., 2000; Kozubska-Sobocińska et al., 2003).

This study was designed to use the heterosomes specific bovine molecular probes to identify sex chromosomes in sheep (Ovis aries), fallow deer (Dama dama), aoudad (Ammotragus lervia) and red deer (Cervus elaphus) and establish genetic conservation of heterosome synteny groups in Ruminantia.

\footnotetext{
*This study was financed from statutory activity, project no. 04-3.05.1.
} 


\section{Material and methods}

Metaphase chromosome spreads of sheep, goat, fallow deer, aoudad and red deer were obtained from peripheral blood lymphocyte culture (pokeweed mitogen stimulated) according to the routine protocol.

In this paper we present identification of heterosomes by FISH technique with two commercial bovine probes (ID Labs): Bovine IDetect ${ }^{\mathrm{TM}} \mathrm{Chr} \mathrm{X}$ Point Probe GREEN - Cat. No. IDBF 1061 and Bovine IDetect ${ }^{\mathrm{TM}}$ Chr Y Point Probe RED - Cat. No. IDBR 1059. Fluorescence in situ hybridization was performed according the manufacturer's procedure. DAPI-banding was applied to precisely identify the chromosome subregions. Hybridization signals were observed under an OPTON-Axiophot fluorescent microscope using triple attenuation filters DAPI/FITC/Texas Red and the computer image analysis system LUCIA-FISH (Laboratory Imaging Ltd, Prague, Czech Republic).

\section{Results}

The results of cross-species hybridizations of sex chromosomes of four species from the suborder Ruminantia with two commercial bovine chromosome painting probes specific for heterosomes (Chr X Point Probe GREEN and Bovine IDetectTM Chr Y Point Probe RED) are displayed in Figure $1 \mathrm{~A}-\mathrm{E}$.

As shown, the distinct red fluorescence signals visible in metaphase plates identify small metacentric chromosomes $\mathrm{Y}$ in sheep (Fig. 1 B), aoudad (Fig. 1 C), red deer (Fig. 1 D) and fallow deer (Fig. 1 E).

In turn, yellow-green fluorescence signals corresponding to acrocentric $\mathrm{X}$ heterosomes in above mentioned species are presented in Figure 1 B-E, respectively.

\section{Discussion}

The first comparative study in the Bovidae family showed band homology on the chromosomes of cattle, sheep, goats and water buffaloes (Evans et al., 1973).

Comparison of GTG-banded, haploid sets of sheep $(2 \mathrm{n}=54)$ and aoudad (Ammotragus lervia) chromosomes $(2 \mathrm{n}=58)$ revealed complete chromosome homology in the karyotypes of both species and indicated that centric fusions of autosomes led to evolutionary rearrangements (Słota et al., 2001).

Karyotype studies of different species of Cervidae family (elk, roe deer, red deer, sika deer and fallow deer) living in the wild, conducted by Gustavsson and Sundt (1968), concerned routinely stained metaphase chromosomes, which were classified according to size and morphology. For the Dama dama species, the $68, \mathrm{XY}$ or $68, \mathrm{XX}$ karyotype as well as the number of arms of autosomal chromosomes (68) were determined. Concerning sex chromosomes, $\mathrm{X}$ was identified as the acrocentric chromosome and $\mathrm{Y}$ as a small submetacentric. 

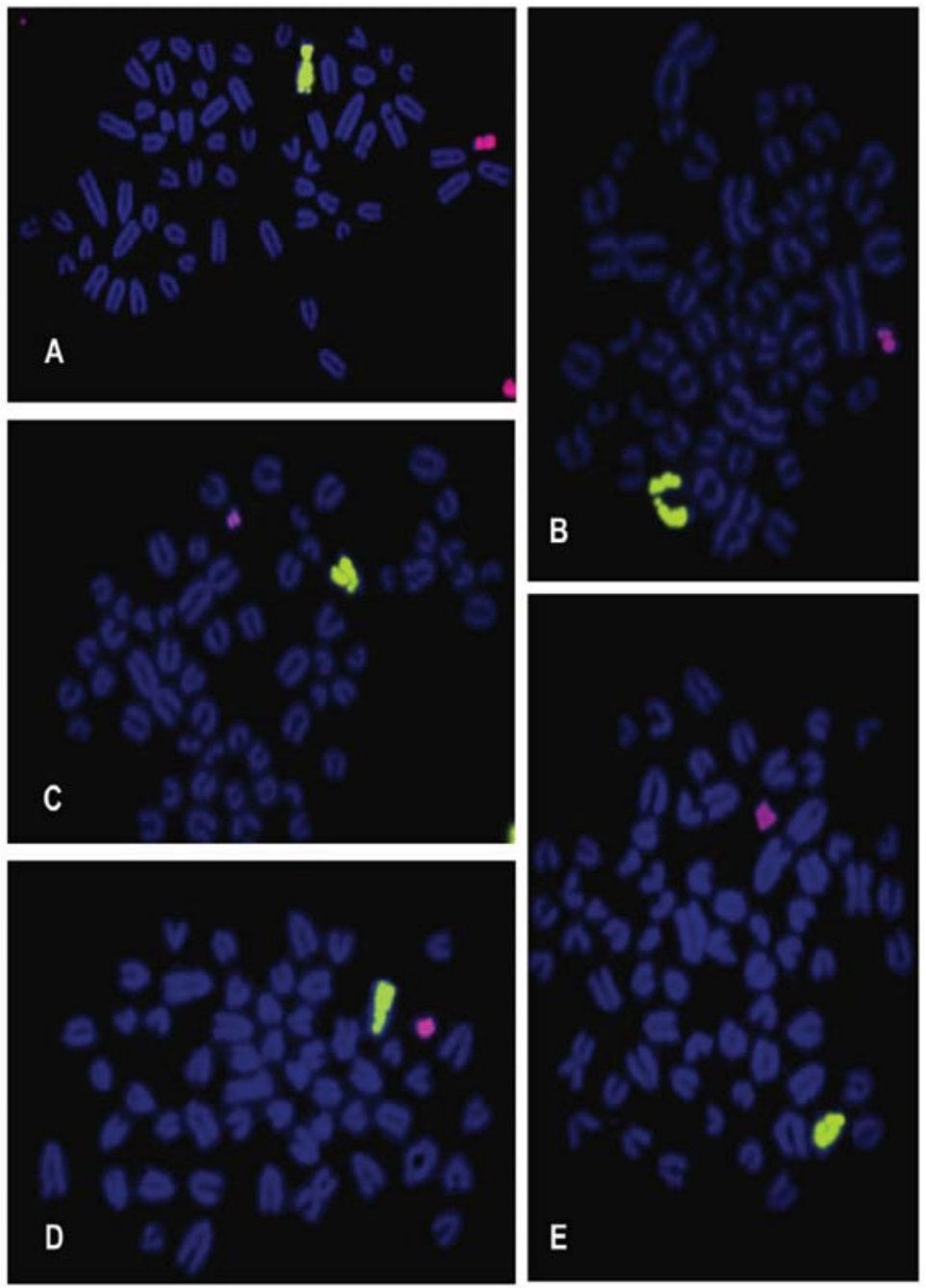

Figure 1. The cross-species hybridizations with bovine probes specific to the heterosomes:

(A) metaphase chromosomes of bull - 60,XY, (B) sheep metaphase plate - 54,XY, (C) aoudad metaphase plate $-58, \mathrm{XY}$, (D) red deer metaphase plate $-68, \mathrm{XY}$, (E) fallow deer metaphase plate $-68, \mathrm{XY}$. Red fluorescence signals identify small metacentric chromosomes $\mathrm{Y}$ in cattle, sheep, aoudad, red deer and fallow deer.

Yellow-green fluorescence signals correspond to acrocentric X heterosomes in sheep, aoudad, red deer and fallow deer and submetacentric $\mathrm{X}$ in cattle.

In the next step of determination the karyotype of fallow deer, the following differential staining techniques were used: GTG, with 350-450 G-bands obtained on metaphase chromosomes (Rubini et al., 1990; Kozubska-Sobocińska et al., 2006, 2007) and RBA, with 527 bands obtained on prometaphase chromosomes (Lioi et al., 1994). 
A remarkable homology of most autosomes of the fallow deer and the roe deer (Capreolus capreolus) were revealed by comparison between the G-banded karyotypes (Rubini et al., 1990). According to these authors, the metacentric pair in the fallow deer retains the same band patterns as the two acrocentric pairs in the roe deer, while the $\mathrm{X}$ chromosomes of the roe deer differ as a result of pericentric inversion.

The comparison of R-banded chromosomes of Vietnamese sika deer (Cervus nippon pseudaxis, $2 \mathrm{n}=66$ ) with bovine $\mathrm{R}$-banded chromosomes was described by Bonnet et al. (2001). Next, the probes for twenty-nine Texas nomenclature type I markers for each cattle autosome, sixteen other type I and fourteen microsatellite markers on sika deer chromosomes were used in FISH technique on sika deer chromosomes. A complete correspondence between sika deer and cattle chromosomes was established; however, autosome pair 7 of sika deer presented the most complex rearrangement as compared with cattle chromosomes.

A complete set of Chinese muntjac chromosome-specific painting probes was used in hybridization in situ to G-banded chromosomes of Chinese muntjac (Muntiacus reevesi), forest musk deer (Moschus berezovskii) and gayal (Bos frontalis) to investigate the karyotype relationships between these three species (Chi et al., 2005). In total, the 22 autosomal painting probes of Chinese muntjac delineated 33 and 34 conserved chromosomal segments in the genomes of forest musk deer and gayal, respectively. The combined analysis of comparative chromosome painting and interspecies G-band comparison revealed a high degree of G-banding patterns conservation of most homologous segments. Interestingly, the musk deer has retained a highly conserved karyotype that closely resembles the proposed ancestral pecoran karyotype but shares none of the rearrangements characteristic of the Cervidae and Bovidae.

In studies on heterosomes conservation in Ruminantia most interspecies hybridizations were based on bovine probes generally (Kozubska-Sobocińska et al., 2003, 2005, 2009 b; Kozubska-Sobocińska and Rejduch, 2008). The only example of using a probe from Bos indicus (obtained from microdissected Yp12 fragment) is identification of a complementary sequence in the X-Y bivalent at metaphase I in Bos taurus and performing comparative hybridization (using the Yq12.1-12.6 probe obtained from Bos indicus) of the appropriate segment on the $\mathrm{q}$ arm of the $\mathrm{Y}$ heterosome in Bos taurus (Goldammer et al., 1996). A probe specific for the Yp12 fragment was also used to identify the $\mathrm{Y}$ chromosome in metaphase plates and spermatozoa (Révay et al., 2000). The high conservation of sex chromosomes in Ruminantia is evidenced by hybridization signals obtained by Révay et al. (2002) for bull spermatozoa, following the application of probes (using FISH) obtained by heterosome sorting of the yak (Bos grunniens).

The study presented in this paper, consisted of using the heterosomes specific bovine molecular probes to identify sex chromosomes in sheep (Ovis aries), fallow deer (Dama dama), aoudad (Ammotragus lervia) and red deer (Cervus elaphus). The experiments carried out revealed genetic conservation of heterosome synteny groups in Ruminantia, which make it possible to apply bovine heterosome probes in cytogenetic diagnostics concerning identification of sex chromosomes in somatic and generative cells. 
It is worth noting that identification of subtle chromosome mutations and intrachromosomal evolutional rearrangements as well as comparative gene mapping need region- or loci-specific probes to be applied in FISH technique (Rejduch et al., 2009, 2010 a).

The results obtained after comparison of Bovidae and Cervidae families belonging to the suborder Ruminantia suggest that genetic conservatism involving gene syntheny of chromosome $\mathrm{X}$ and chromosome $\mathrm{Y}$ is the phenomenon frequently observed also between larger systematic units than family.

\section{References}

B o n n e t A., The ve no n S., C l a ro F., G a u ti e r M., H a y e s H. (2001). Cytogenetic comparison between Vietnamese sika deer and cattle: R-banded karyotypes and FISH mapping. Chromosome Res., 9: 673-687.

Chi J., Fu B., Nie W., Wang J., Graphodatsky A.S., Yang F. (2005). New insights into the karyotypic relationships of Chinese muntjac (Muntiacus reevesi), forest musk deer (Moschus berezovskii) and gayal (Bos frontalis). Cytogenet. Genome Res., 108: 310-316.

Chowdhary B.P., Frönicke L., Gustav s s on I., Sherthan H. (1996). Comparative analysis of the cattle and human genomes: detection of ZOO-FISH and gene mapping-based chromosomal homologies. Mamm. Genome, 7: 297-302.

Danielak-Czech B., Kozubska-Sobocińska A., Rejduch B. (2010). Diagnosis of tandem fusion translocation in the boar using FISH technique with human painting probes. Ann. Anim. Sci., 10: 361-366.

Di Berardino D., Di Meo G.P., Gallagher D.S., Hayes H., I annuzzi L. (2001). International system for chromosome nomenclature of domestic bovids. Cytogenet. Cell Genet., 92: 283-299.

Evan s H.J., B u c k land R.A., S u m m ner A. (1973). Chromosome homology and heterochromatin in goat, sheep and ox studied by banding techniques. Chromosoma, 48: 383-402.

Gold a m mer T., B rurmer R.M., Weikard R., S chwerin M. (1996). Generation and use of chromosome fragment specific bovine DNA probes for cytogenetic studies in cattle. Arch. Zootec., 45: 309-314.

Gu st a v s s on I., S und t C.O. (1968). Karyotypes in five species of deer (Alces alces L., Capreolus capreolus L., Cervus elaphus L., Cervus nippon nippon Temm. and Dama dama L.). Hereditas, 30 : 233-248.

H a y e s H. (1995). Chromosome painting with human chromosome-specific DNA libraries reveals the extent and distribution of conserved segments in bovine chromosomes. Cytogenet. Cell Genet., 71: $168-174$.

Kozubska-Sobocińska A., Słota E., Pieńkowska A. (2003). Application of FISH technique for diagnosis of leukocytic chimerism in sheep (in Polish). Med. Weter., 59: 987-989.

Kozubska-Sobocińska A., Słota E., Pieńkowska-Schelling A., Schelling C. (2005). Comparative hybridization of the Y chromosome in selected species of Bovidae. Ann. Anim. Sci., 5: 5-9.

Ko zubsk a-S ob o c ińsk a A., S to ta E., P a k u s i ew i c z M. (2006). Comparison of the G-banded karyotype of the fallow deer (Dama dama) and sheep (Ovis aries). Ann. Anim. Sci., 6: 225-231.

Kozubska-Sobocińska A., Ząbek T., Słota E., Kaczor U. (2007). Comparison of GTG-banded karyotypes and microsatellite sequences in some species of the Bovidae and Cervidae families. J. Anim. Feed Sci., 16: 567-578.

Kozubska-Sobocińska A., Rejduch B. (2008). Identification of heterosomes in spermatozoa of rams with 54,XX/54,XY chimerism. Vet. Med.-Czech, 53: 250-254.

Kozubska-Sobocińska A., Rejduch B., Kaczor U., Sharan M. (2009 a). Microsatellite sequences of Y heterosome. The Animal Biology - Scientific-theoretical Journal of Ukrainian Academy of Agrarian Sciences, 11: 247-250. 
Kozubska-S obocińska A., Bugno-Poniewierska M., Słota E. (2009 b). Application of bovine heterosome painting probes to analysis of the sex bivalent in rams. Ann. Anim. Sci., 9: 371-378.

L i o i M.B., S c arfi M.R., Di B erardino D. (1994). The RBA-banded karyotype of the fallow deer (Dama dama L.). Cytogenet. Cell Genet., 67: 75-80.

Rejduch B., Kozubska-S obocińska A., Ka c zor U. (2009). Genetic conservation of the INS-IGF2-H19 gene cluster in pigs. The Animal Biology - Scientific-theoretical Journal of Ukrainian Academy of Agrarian Sciences, 11: 255-258.

Rejduch B., Danielak-Czech B., Kozubska-Sobocińska A. (2010 a). FISH-based comparative analysis of human and porcine chromosome region involving obesity-related genes. Ann. Anim. Sci., 10: 367-372.

Rejduch B., Kozubska-S obocińska A., Danielak-Czech B. (2010 b). Use of human painting probes for identification of centric fusion in wild boar. Chromosome Res., 18: 727-728.

Révay T., T ardy E.P., T óth A., Kovács A., S a lgó A. (2000). Sexing bovine cells by FISH with a synthetic Y-probe. Proc. 14th Europ. Colloq. Cytogenet. Domest. Anim., Abstr., Brno, p. 29.

Révay T., Kovacs A., Rens W., Gustavs on I. (2002). Simultaneous detection of viability and sex of bovine spermatozoa. Reprod. Fert. Develop., 14: 373-376.

R u b in i M., N e gri E., F o n t a n a F. (1990). Standard karyotype and chromosomal evolution of the fallow deer (Dama dama L.). Cytobios, 64: 155-161.

Słota E., Kozubska-Sobocińska A., Bugno M., Giemza-Marek A., Kulig B. (2001). Comparison between the G-banded karyotype of the aoudad (Ammotragus lervia) and sheep (Ovis aries). J. Appl. Genet., 42: 59-64.

Accepted for printing 5 IX 2012

\title{
ANNA KOZUBSKA-SOBOCIŃSKA, BARBARA REJDUCH, BARBARA DANIELAK-CZECH, MAREK BABICZ, AGNIESZKA BĄK
}

Hybrydyzacje porównawcze chromosomów płci u Ruminantia

\author{
STRESZCZENIE
}

Synteniczno-konserwatywny charakter wielu chromosomów umożliwia wykorzystanie licznych sond molekularnych, otrzymanych dla jednego gatunku zwierząt, do detekcji homologicznych fragmentów DNA u innych gatunków. Celem tych badań była analiza homologii między chromosomami płci u kilku gatunków należących do podrzędu Ruminantia (owcy - Ovis aries, daniela - Dama dama, owcy grzywiastej - Ammotragus lervia, jelenia szlachetnego - Cervus elaphus) przy zastosowaniu techniki FISH i bydlęcych sond malujących heterosomy. Uzyskane wyniki ujawniły mocne czerwone sygnały fluorescencyjne na małych metacentrycznych heterosomach Y i wyraźne żółto-zielone sygnały w dużych akrocentrycznych chromosomach X u wszystkich porównywanych gatunków. 